\title{
Kết quả bước đầu phân tích đa hình thái đơn gen NPHS2 ở bệnh nhi mắc hội chứng thận hư tiên phát
}

\author{
Phạm Thị Hồng Nhung, Trần Vũ Quỳnh Giao, Vũ Vân Nga, Phạm Văn Đếm, \\ Nguyễn Thị Thúy Mậu, Đinh Đoàn Long, Vũ Thị Thơm*
}

Khoa Y Duợc, Đại học Quốc gia Hà Nội, 144 Xuân Thủy, Cầu Giấy, Hà Nội, Việt Nam

Nhận ngày 21 tháng 2 năm 2017

Chỉnh sửa ngày 08 tháng 4 năm 2017; Chấp nhận đăng ngày 14 tháng 6 năm 2017

\begin{abstract}
Tóm tắt: NPHS2 là gen mã hóa cho protein podocin. Nhiều nghiên cứu trên thế giới chỉ ra đột biến gen này là nguyên nhân chính gây nên hội chứng thận hư (HCTH) khởi phát sớm ở trẻ nhỏ và HCTH kháng corticosteroid. Chính vì vậy, chúng tôi tiến hành nghiên cứu phân tích kiểu gen 6 exon của gen NPHS2 trên nhóm 149 bệnh nhi mắc hội chứng thận hư tiên phát ở Viện Nhi trung ương. Phương pháp nghiên cứu chính được sử dụng bao gồm tách DNA tổng số từ mẫu máu ngoại vi, khuếch đại gen bằng $\mathrm{PCR}$, xác định kiểu gen bằng phương pháp giải trình tự Sanger. Kết quả nghiên cứu cho thấy chúng tôi đã xây dựng được quy trình phân tích kiểu gen 6 exon của gen NPHS2 với cùng một điều kiện phản ứng $\mathrm{PCR}$ và bước đầu có những kết quả với $251 \mathrm{SNP}$ được phát hiện, trong đó có 2 vị trí xuất hiện SNP mới ở exon 2 và exon 3 . Đây là kết quả hết sức có ý nghĩa để giúp cho những nghiên cứu sau này về mối liên quan giữa kiểu gen và nguy cơ mắc HCTH kháng corticosteroid ở trẻ em mắc HCTH tiên phát người Việt Nam.
\end{abstract}

Tư khóa: NPHS2, podocin, hội chứng thận hư.

\section{1. Đặt vấn đề}

Hội chứng thận hư $(\mathrm{HCTH})$ là bệnh về cầu thận thường gặp nhất ở trẻ em [1]. Khoảng 20\% bênh nhân không có đáp ứng sau điều trị với corticosteroid (nhóm HCTH kháng steroid) và các thuốc ức chế miễn dịch khác, trong đó $50 \%$ bệnh nhân sẽ triển thành suy thận hoặc bệnh thận giai đoạn cuối gây ảnh hưởng rất lớn đến sức khỏe và cuộc sống của trẻ cũng như gia đình [2]. Các nghiên cứu phân tử hiện nay đã xác định được một số gen mã hóa cho các protein có vai trò chính đảm bảo tính toàn vẹn của hàng rào lọc cầu thận, trong đó phải kể đến podocin [3]. Podocin được mã hóa bởi gen NPHS2 gồm 8 exon nằm trên vai dài của nhiễm sắc thể số 1 ở người (1q25-q31) [4]. Bằng

\footnotetext{
Tác giả liên hệ. ĐT.: 84-1677968818.

Email: thomtbk5@gmail.com

https://doi.org/10.25073/2588-1132/vnumps.4071
}

những bằng chứng trên động vật thực nghiệm knock out gen $N P H S 2$ và những bằng chứng phân tích mối liên quan giữa đa hình di truyền gen này với HCTH kháng steroid ở trẻ em, các nhà khoa học đã chứng minh được đột biến gen NPHS2 có liên quan chặt chẽ tới hội chứng thận hư tiên phát kháng corticosteroid $[5,6]$. Phân tích đột biến gen NPHS2 có thể giúp sáng tỏ nguyên nhân kháng thuốc để bệnh nhân không phải chịu đựng những tác dụng phụ và các biến chứng nặng nề khi phải điều trị bằng các thuốc ức chế miễn dịch. Tại Việt Nam dù đã một số nghiên cứu lâm sàng về HCTH kháng corticosteroid nhưng chưa có nghiên cứu nào về đa hình di truyền trên bệnh nhân mắc $\mathrm{HCTH}$ thể kháng costicosteroid được công bố.Từ nhu cầu lâm sàng, chúng tôi tiến hành nghiên cứu để thiết lập quy trình phân tích kiểu gen 6 exon của gen NPHS2. 


\section{Nguyên liệu và phương pháp nghiên cứu}

Thu thập và bảo quản mẫu sinh phẩm: 149 mẫu máu toàn phần $(2 \mathrm{ml})$ bảo quản trong EDTA lưu ở $-20^{\circ} \mathrm{C}$ dến khi sử dụng.

Tách chiết DNA tổng số: DNA tổng số được tách từ mẫu máu toàn phần, chúng tôi sử dụng E.Z.N.A blood DNA Mini kit (OmegaBiotek) theo quy trình khuyến cáo của hãng

Thiết kế mồi đặc hiệu cho 6 exon của gen NPHS2: Cặp mồi được thiết kế và đánh giá các thông số với phần mềm PerlPrimer version 1.1.14. Cặp mồi tự thiết kế được đặt tổng hợp tại hãng IDT (Mỹ) với trình tự được trình bày trong bảng 1 .

Bảng 1. Trình tự mồi nhân dòng gen NPHS2

\begin{tabular}{clc}
\hline Exon & \multicolumn{1}{c}{ Trình tự mồi } & $\begin{array}{c}\text { Độ dài } \\
\text { sản } \\
\text { phẩm }\end{array}$ \\
\hline 1 & $\begin{array}{l}\text { GCA GCG ACT CCA CAG GGA CT } \\
\text { TCC ACC TTA TCT GAC GCC CC }\end{array}$ & 414 bp \\
2 & $\begin{array}{l}\text { CTCTGACTACTCTGATTTGACT } \\
\text { GGCTTCCTGTTCACATTTGAG }\end{array}$ & 203 bp \\
3 & $\begin{array}{l}\text { CTA GGA TCA TTC TTA TGC CA } \\
\text { GAGGTCCATATTACA AAT CTG C }\end{array}$ & 238 bp \\
4 & $\begin{array}{l}\text { TCC CTG TTT ATA CCTATT GTC C } \\
\text { CCC ATT CCC TAG ATT GCC }\end{array}$ & 475 bp \\
5 & $\begin{array}{l}\text { AAA GGA GCC CAA GAA TCA AG } \\
\text { AAA TAT TTC AGC ATA TTG GCC }\end{array}$ & 292 bp \\
6 & $\begin{array}{l}\text { GTT TAG GCA TGC TCT CCT C } \\
\text { GATATGGCTATAGTA CTC AGT G }\end{array}$ & 228 bp \\
\hline
\end{tabular}

Nhân dòng 6 exon của gen NPHS2 bằng PCR: Để có quy trình nhân dòng đặc hiệu và ổn định, nhiệt độ gắn mồi, nồng độ hoạt động tối ưu của các thành phần trong phản ứng $\mathrm{PCR}$ sử dụng Pfu DNA polymerase được xác định. Sản phẩm PCR được điện di trên gel agarose $1.5 \%$, dùng thang chuẩn Ruler $100 \mathrm{bp}$ Plus DNA Ladder (SM0321, Thermo Scientific) và hình ảnh được ghi lại bằng hệ thống chụp ảnh điện di Gel-Doc It.

Xác định kiểu gen 6 exon gen NPHS2 bằng phương pháp giải trình tư: $20 \mu \mathrm{l}$ sản phẩm PCR được tinh sạch bằng kit E.Z.N.A. ${ }^{\circledR}$ Cycle-Pure Kit (Omega-biotek) và giải trình tự sử dụng máy phân tích phân đoạn DNA tự động
3500 (Applied Biosystems) và kit $\mathrm{BigDye}{ }^{\circledR}$ Terminator v3.1 cycle sequencing (Applied Biosystems). Kết quả giải trình tự được mở bằng phần mềm BioEdit version 7.1.9, qua đó xác định kiểu gen của bệnh nhân.

\section{Kết quả và thảo luận}

Tách chiết DNA tổng số: 149 mẫu máu toàn phần đều tách được DNA tổng số nhờ sử dụng kit E.Z.N.A blood DNA Mini kit (OmegaBiotek). Nồng độ DNA dao động từ 31.7 $353.65 \mathrm{ng} / \mu \mathrm{l}$. Mẫu có độ tinh sạch cao, 131/150 $(87.33 \%)$ mẫu có chỉ số A260/280 trong khoảng 1.7-2.0. Ngoài ra, chất lượng của mẫu $\mathrm{ADN}$ tổng số được kiểm chứng bằng phương pháp điện di cho kết quả như ở hình 1 . Kết quả điện di cho thấy hình ảnh một băng sáng rõ, $\mathrm{ADN}$ không bị đứt gãy đủ điều kiện để tiến hành phản ứng nhân dòng tiếp theo bằng phương pháp PCR.

$$
\begin{array}{llllllllllll}
\text { M } & 1 & 2 & 3 & 4 & 5 & 6 & 7 & 8 & 9 & 10 & 11
\end{array}
$$

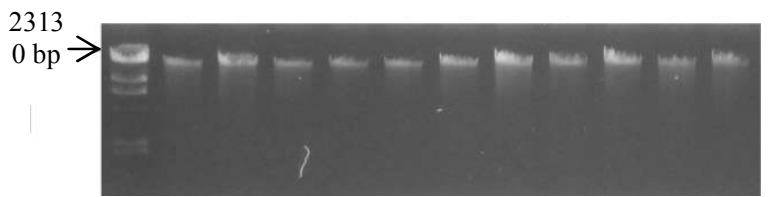

Hình 1. Ảnh điện di trên gel agarose $0,7 \%$ của ADN tổng số tách từ mẫu máu toàn phần của bệnh nhân. M là marker; 1-11 là số thứ tự của mẫu $\mathrm{ADN}$ tổng số của 11 bệnh nhân.

Nhân dòng 6 exon của gen NPHS2 bằng $P C R$ : cả 6 exon đều nhân dòng thành công với cùng một điều kiện $\mathrm{PCR}$ được trình bày trong bảng 2 :

\begin{tabular}{ll}
\hline Hóa chất & Nồng độ \\
\hline dNTP Mix & $0.2 \mathrm{mM}$ \\
Pfu DNA polymerase & $0,05 \mathrm{u} / \mu \mathrm{l}$ \\
Mồi (mỗi loại) & $0.3 \mu \mathrm{M}$ \\
DNA & $50-100 \mathrm{ng} / \mu \mathrm{l}$ \\
\hline
\end{tabular}

Chu trình nhiệt cho phản ứng PCR gồm 3 giai đoạn: biến tính ban đầu $95^{\circ} \mathrm{C}$ trong 3 phút; 35 chu kì: $95^{\circ} \mathrm{C}$ trong 30 giây, gắn mồi ơ $56^{\circ} \mathrm{C}$ trong 30 giây, $72^{\circ} \mathrm{C}$ trong 1 phút; thời gian kéo dài cuối $72^{\circ} \mathrm{C}$ trong 5 phút. Chất lượng PCR được minh họa bằng ảnh điện di cho exon 2 ở hình 1 . 


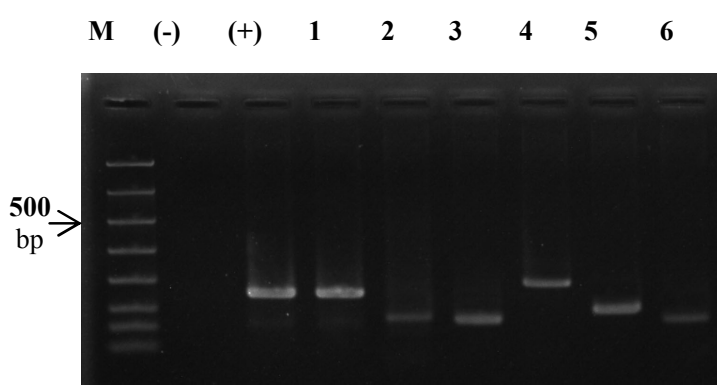

Hình 2. Ảnh điện di trên gel agarose $1.5 \%$ của thí nghiệm PCR exon 1-6 của gen NPHS2. M: marker; (-): Đối chứng âm; (+): Đối chứng dương; 1-6 là ký hiệu tương ứng từ exon 1 đến exon 6 .

Trong tối ưu quy trình để xác định trình tự của một gen kích thước lớn với nhiều exon, việc đưa được phản ứng PCR để nhân dòng tất cả các exon về cùng một điều kiện có ý nghĩa rất quan trọng trong ứng dụng thực tế để chẩn đoán bệnh. Ở nghiên cứu này, chúng tôi đã thực hiện được việc nhân dòng thành công 6 exon của gen NPHS2 trong cùng một điều kiện như trình bày ở trên, qua đó tiết kiệm thời gian và công sức của người thực hiện một cách đáng kể. Xác định kiểu gen NPHS2 bằng phương pháp giải trình tự: Dưa vào kết quả giải trình tư, kết hơp với cơ sở dũ liệu trên NCBI chúng tôi xác định được các SNP xuất hiện ở 6 exon nhu trình bày ở Bảng 2.

Bảng 2. Các SNP xuất hiện trên 6 exon của gen NPHS2

\begin{tabular}{ll}
\hline Exon & Các SNP \\
\hline 1 & $\begin{array}{l}\text { 72 SNP; rs1079292; rs7585644 xuất hiện } \\
\text { đa hình }\end{array}$ \\
& $\begin{array}{l}\text { 44 SNP; rs3738423 xuất hiện đa hình; } \\
\text { xuất hiện đa hình mới (A/T) ở vị trí 161 } \\
\text { với kiểu gen dị hợp tử }\end{array}$ \\
& $\begin{array}{l}\text { 32 SNP; rs200437667 xuất hiện đa hình; } \\
\text { xuất hiện đa hình mới (T/A) ở vị trí 130 }\end{array}$ \\
& với kiêu gen đồng hợp tử kiểu đột biến \\
& 37 SNP; rs12401711; rs12401708; \\
& rs528833893 xuất hiện đa hình \\
5 & 49 SNP; không xuất hiện đa hình \\
6 & 17 SNP; không xuất hiện đa hình \\
\hline
\end{tabular}

Trên thế giới, đã có nhiều công bố về đa hình gen NPHS2 ở các quốc gia khác nhau.
Năm 2002, nhóm Frishberg đã phân tích kiểu gen của 27 bệnh nhân người Israel-Ả Rập thấy có đột biến trong gen NPHS2 chịu trách nhiệm mã hóa ống thận. Đây là thể hay gặp của hội chứng thận hư kháng steroid ở trẻ em Israel-Ả Rập. Kết quả cho thấy 15 bệnh nhân $(55 \%)$ là đồng hợp tử đột biến (R138X) và đều có cùng một haplotype đồng hợp tử đa hình A1023G [7]. Năm 2007, Berdeli nghiên cứu đột biến gen NPHS2 trên 295 trẻ em ở Thổ Nhĩ Kỳ mắc HCTH tiên phát kháng thuốc thấy: Bốn mươi mốt bệnh nhân $(13,8 \%)$ có tiền sử gia đình và 254 bệnh nhân $(86,2 \%)$ là ngẫu nhiên. Phân tích đột biến đã được thực hiện trong tất cả tám exon của gen $N P H S 2$ với phương pháp trình tự ADN trực tiếp. Có 53 đột biến NPHS2 bệnh sinh khác nhau được phát hiện, trong đó có 37 đột biến mới. Tỷ lệ phát hiện đột biến là $24,7 \%$ cho tất cả các bệnh nhân, $29,2 \%$ cho nhóm có tiền sử gia đình, $24 \%$ cho nhóm ngẫu nhiên. Trong số những bệnh nhân có đột biến, tỷ lệ suy thận và / hoặc giai đoạn cuối bệnh thận (26\%) cao hơn so với những người không có đột biến $(12,6 \%)$ một cách đáng kể [8]. Năm 2013, Basiratnia và cộng sự đã nghiên cứu trên 99 trẻ em mắc hội chứng thận thư ở Tây Nam Iran trong đó có 49 trẻ em mắc HCTH kháng thuốc và 50 trẻ em với HCTH nhạy thuốc và đề xuất phác đồ điều trị mới cho trẻ mắc $\mathrm{HCTH}$ kháng thuốc dựa trên xác định các đột biến gen này [9]. Năm 2014, Tory và cộng sự, nghiên cứu trên 318 bệnh nhân người Pháp mắc $\mathrm{HCTH}$ kháng thuốc, trong đó có 71 trường hợp khởi phát muộn và 247 trường hợp khởi phát sớm cũng chứng minh mối liên hệ chặt chẽ giữa HCTH kháng thuốc với đa hình di truyền gen NPHS2 trên cả 8 exon [12]. Tại Việt Nam, đây là công bố đầu tiên về kết quả giải trình tự toàn bộ exon trên gen NPHS2 ở bệnh nhân nhi người Việt Nam mắc hội chứng thận hư tiên phát. Trong đó, chúng tôi phát hiện có 152 SNP với 7 SNP xuất hiện đa hình trên exon $1,2,3$ và 4 . Tại exon 5 và 6 , không có SNP nào xuất hiện đa hình. Kết quả này phù hợp với một số nghiên cứu trên trẻ em Iran mắc HCTH kháng thuốc giai đoạn muộn $(n=25)$ hoặc trên bệnh nhân $\mathrm{HCTH}$ kháng thuốc giai đoạn sớm $(n=20)$ không tìm thấy 
đa hình nào của NPHS2 trên exon 5 và $7[10,11]$. Bên cạnh những đa hình đã được công bố, chúng tôi lần đầu tiên phát hiện hai đột biến mới nằm trên exon 2 và exon 3 của gen $N P H S 2$ ở bệnh nhân nhi mắc HCTHTP. Liệu hai đột biến mới này có ý nghĩa gì trong hội chứng thận hư tiên phát kháng corticosteroid hay không, cần có những nghiên cứu tiếp theo để kiểm chứng giả thuyết này.

\section{Kết luận}

Chúng tôi đã xây dựng được quy trình xác định đa hình thái đơn (SNP) trên 6 exon thuộc gen $N P H S 2$ và áp dụng thành công quy trình này phân tích gen trên nhóm bệnh nhân nhi mắc hội chứng thận hư tiên phát.

\section{Lò̀i cảm ơn}

Chúng tôi trân trọng cảm ơn sự tài trợ của Đại học Quốc gia Hà Nội cho đề tài mã số QG.16.23 để thực hiện nghiên cứu này.

\section{Tài liệu tham khảo}

[1] Yu Z, Ding J, Huang J, Yao Y, Xiao H, Zhang J, Mutations in NPHS2 in sporadic steroid resistant nephrotic syndrome in Chinese children. Nephrol Dial Transplant, (2005) 20:902-8.

[2] Otukesh H, Otukesh S, Mojtahedzadeh M, Hoseini R, Fereshtehnejad SM, Riahi FA, Management and outcome of steroid-resistant nephrotic syndrome in children, IJKD, (2009) 3:210-7.

[3] Cho YH, Lee HJ, Choi JH, Lee HB, Ha SH, Choi Y, WT1 and NPHS2 mutations in Korean children with steroid resistant nephrotic syndrome. Pediatr Nephrol, (2008) 23:63-70.
[4] Franceschini N, North KE, Kopp JB, Mckenzie L, Winkler C, NPHS2 gene, nephritic syndrome and focal segmental glomerulosclerosis: a huge review, Genetics in Medicine, (2006) 8:63-75.

[5] Caridi G, Perfumo F, Ghiggeri GM, NPHS2 (podocin) mutations in nephrotic syndrome, Clinical Spectrum and Fine Mechanism, Pediatric Research, (2005) 57:54R-61R.

[6] Boute N, Gribouval O, Roselli S, Benessy F, Lee H, Fuchshuber A, Dahan K, Gubler MC, Niaudet $\mathrm{P}$, Antignac C, NPHS2, encoding the glomerular protein podocin, is mutated in autosomal recessive steroid resistant nephritic syndrome, Nature genetics, (2000) 24:349-354.

[7] Frishberg Y, Megged O, Shapira E, Feinstein S, Raas-Rothschild A, Mutations in NPHS2 encoding podocin are a prevalent cause of steroid resistant nephritic syndrome among Israeli-Arab children, J Am Soc Nephrol, (2002) 13(2): 400-405.

[8] Berdeli A, Yavascan O, Serdaroqlu E, Bak M, Aksu N, Oner A, Anarat A, Donmez O, Yildiz N, Sever L, Tabel Y, Dusunsel R, Sonmez F, Cakar N, NPHS2 (podocin) mutations in Turkish children with idiopathic nephritic syndrome, Pediatr Nephrol, (2007) 22: 2031-2040

[9] Basiratnia M, Torabinezhad S, Erjaee A, NPHS2 gene in Steroid resistant nephritic syndrome. Prevelance, clinical course, and mutational spectrum in South West Iranian children, IJKD, (2013) 7: 357-362.

[10] Otukesh H, Fereshtehnejad SM, Bakhshayesh M, Hashemi M, Hoseini R, Chalian M, Salami A, Mehdipor L, Rahiminia A, NPHS2 Mutations in Children with Steroid-Resistant Nephrotic syndrome, Iranian Journal of Kidney Diseases, (2009) 3: 99-102.

[11] Fotouhi N, Bonyadi MJ, Abdolmohammadi R, Kamalifar A, Nasri H, Einollahi B, R229Q polymorphism of NPHS2 gene in patients with late-onset steroid resistance nephritic syndrome. A Preliminary study, IJKD, (2013) 7: 399-403.

[12] Karle SM, Ronner V, Glaeser L, Hildebrandt F, Fuchshuber A, Novel mutations in NPHS2 detected in both familial and sporadic steroidresistant nephrotic syndrome, J Am Soc Nephrol, (2002) 13: 388-393. 


\title{
Initial Results in Genotyping of 6 Exons of NPHS2 Gene in Pediatric Patients with Nephrotic Syndrome
}

\author{
Pham Thi Hong Nhung, Tran Vu Quynh Giao, Vu Van Nga, Pham Van Dem, \\ Nguyen Thi Thuy Mau, Dinh Doan Long, Vu Thi Thom \\ VNU School of Medicine and Pharmacy - Vietnam National University, \\ 144 Xuan Thuy, Cau Giay, Hanoi, Vietnam
}

\begin{abstract}
NPHS2 is gene coding for podocin protein that plays an important role in nephrotic syndrome. Many studies showed NPHS2 causing early onset and not responding to standard steroid treatment in pediatric patients with nephrotic syndrome. In this study, we established the genotyping method of 6 exons of NPHS2 in pediatric patient blood samples collecting in National Pediatric Hospital. Blood samples was extracted DNA and amplified wanted gene by PCR. Different PCR conditions was tested, then optimal PCR product was sequenced. From sequencing results, 251 SNPs from 6 exons was detected including 7 SNPs with various polymorphism; 2 new SNPs in exon 2 and exon 3. In conclusion, we were successfully establishing the genotyping method of all 6 exons of NPHS2 in one PCR procedure and got some first results that would be useful for our next clinical study on Vietnamese pediatric patients with nephrotic syndrome.
\end{abstract}

Keywords: NPHS2, podocin, nephrotic syndrome. 